\title{
Productivity of Local Goats Supplemented with Acacia villosa and Coripha gebanga
}

\author{
A. M. Fuah* \& W. A. Pattie \\ Department of Animal Production and Technology, Faculty of Animal Science, Bogor Agricultural University \\ Jln. Agatis, Kampus IPB Darmaga, Bogor 16680, Indonesia \\ (Received 22-10-2012; Reviewed 22-01-2013; Accepted 28-03-2013)
}

\begin{abstract}
Most feed for goats in the villages of West Timor, Indonesia, came from communal grazing areas, consist of native grass during wet season, crop residues and tree leaves (Sesbania and Acacia species) in dry season. This study was aiming at examining the growth of goat supplemented with local feed. Twenty four goats were used, the average initial live weight was $12.5 \mathrm{~kg}$. Four feeding treatments were applied: T1-200 g cut grass; T2-200 g Acacia villosa; T3-200 g Coripha gebanga; T4-100 g A. villosa $+100 \mathrm{~g}$ C. gebanga. Live weights and feed consumption were analyzed using repeated measures, analysis of variance. The average live weight showed a small increase, as well as daily weight gain of goats of which different significantly $(\mathrm{P}<0.05)$ amongst treatments $(17,36,42$, and $43 \mathrm{~g} / \mathrm{d} / \mathrm{head})$, during the first $6 \mathrm{wk}$, followed by a sharp drop after $8 \mathrm{wk}$. The average supplemented feed consumption was $52,35,85$, and $75 \mathrm{~g} / \mathrm{d} /$ animal, for cut grass, A. villosa, C. gebanga, and A. villosa plus $C$. gebanga, respectively. Goats given $C$. gebanga and mixed Acacia and $C$. gebanga gave higher average weight gain, but also consumed more feed than those given cut grass or A.villosa $(\mathrm{P}<0.01)$. Supplementing feed to maintain growth of goats during dry seasons was better on $A$. villosa than on palm pith and its combination.
\end{abstract}

Key words: productivity, local goat, Acacia villosa, Corypha gebanga

\section{ABSTRAK}

Sebagian besar pakan kambing di Timor, Indonesia, berasal dari padang penggembalaan, terdiri atas rumput lokal pada musim hujan, serta daun akasia, sesbania, gliricidia, dan berbagai limbah pertanian pada musim kemarau. Penelitian ini bertujuan mempelajari pertumbuhan ternak kambing yang disuplementasi pakan lokal. Dua puluh empat ekor kambing, dengan rataan bobot awal 12,5 kg, diberi pakan tambahan selama 17 minggu dengan perlakuan: P1) rumput lapang; P2) $200 \mathrm{~g}$ daun akasia; P3) $200 \mathrm{~g}$ sagu; P4) $100 \mathrm{~g}$ daun akasia dan $100 \mathrm{~g}$ sagu. Pakan tambahan diberikan pada sore hari saat ternak dikandangkan. Bobot badan ditimbang setiap minggu, untuk memperoleh data pertambahan bobot badan $(\mathrm{pbb})$ dan konsumsi ransum. Metoda analisis adalah repeated mesurement, analysis of variance. Rataan bobot badan kambing selama 6 minggu pertama menunjukkan peningkatan, dengan nilai pbb untuk P1, P2, P3, dan P4 sebesar 17, 36, 42, dan 43 g/hari), dan berbeda nyata $(\mathrm{P}<0,05)$ antar perlakuan. Rataan konsumsi pakan ternak yang diberi rumput lapang, akasia, sagu dan kombinasi akasia-sagu: 52, 35, 85, dan 75 g/hari. Hasil analisis menunjukkan bahwa konsumsi sagu dan kombinasi akasia-sagu, lebih tinggi $(\mathrm{P}<0,01)$ dibandingkan dengan perlakuan lainnya. Suplementasi akasia mampu mempertahankan pertumbuhan ternak kambing pada saat kekurangan pakan di musim kemarau.

Kata kunci: produktivitas, kambing, Acacia villosa, Corypha gebanga

\section{INTRODUCTION}

The majority of goat and sheep production in Indonesia is in the hands of small land owners and

*Corresponding author:

E-mail: asnath_95@yahoo.com landless farmers, therefore, poor management and nutrition are common place and the potential of the animal is rarely realized. A number of studies have been conducted on kacang goat productivity (Padang \& Irmawati, 2007; Adriani, 2009), behaviour and feeding management (Setianah et al., 2004; Sitorus 2004), including the economic efficiency in raising small ruminants (Ishaq et al., 2010; Cyrilla et al., 2010). In eastern part of 
Indonesia, especially in West Timor, weights of male and female kids at two weeks of age were about 3.9 and $3.2 \mathrm{~kg}$, respectively. The average weight gain of goats across the region was approximately $25 \mathrm{~g} / \mathrm{d}$, which was much lower than the local (Kacang) goats in west region of Indonesia, as well as in other Asean countries, of about $50 \mathrm{~g} / \mathrm{d}$, and could achieve $157 \mathrm{~g} / \mathrm{d}$ on goats treated under experimental station (Johnson et al., 1986). The constraint area diagnosed as having serious impact on goat productivity was animal feeding and nutrition. Beside natural grasses of which less available during dry seasons and low in nutrient contents, some local forages, legumes and tree leaves such as Acacia villosa, Sesbania grandiflora, kapok, Coripha gebanga pith and crop byproducts were the available feedstuff for goats in West Timor (Mulik \& Permana, 2009). The prospect of those feeds as supplement for improving goat production was significant (Simon \& Ginting, 2005), taking into account the nutrient content and the utilization (Simon et al., 2006). A. villosa leaves was usually used in ruminant animal feeding, due to its high protein content ranged between 13\%-32\% (Tangendjaja \& Wina, 2000). Mulik \& Permana (2009) reported the higher crude protein of A. villosa than of natural grass in West Timor (213 g vs $57 \mathrm{~g} / \mathrm{kg} \mathrm{DM}$ ), although the anti nutrient factors (tannin) could limit its utilization (Reed, 1995). Whereas, the C. gebanga is used as the source of carbohydrates and also protein. Known as 'sagu', C. gebanga, is normally used for human food as noodle (Lestari, 2009), in Papua, Maluku, Sulawesi (Kanro et al., 2003), and also as animal feed in East Nusa Tenggara (Mulik \& Permana, 2009).

Low growth rate of goats were diagnosed as major constraints in goat husbandry, especially during dry seasons when feed was less available. A. villosa and palm pith (C. gebanga) were locally available all year round at the village sites, were considered promising as feed supplements for improving goat productivity. Therefore, supplementary feeding trials were designed and tested on the growing age of local goats. In this experimental study, feeding trials on goats were undertaken under research station conditions, using $A$. villosa and the of pith C. gebanga. The objectives of the study were to assess the effect of the supplementary feeding trial on live weight, growth rate, feed consumption and efficiency of local goats.

\section{MATERIALS AND METHODS}

\section{Feeding Trial}

A feeding trial was carried out at the Animal Research Station at Lili, Kupang of West Timor, Indonesia, to determine whether the feed supplementation used for goats (based on supplements used by some farmers) was effective and generally viable. The study was designed to examine the effect of feed supplementation with palm pith and Acacia leaves on the performance of local goats, under a combined grazing (day-time) and confinement (night time) system of management.

Twenty four local goats, consisting of 16 females and 8 males were used in the experiment, with the age of the goats ranged from 7 to $9 \mathrm{mo}$, and initial live weight was $12.5 \mathrm{~kg}(9.5-14.5 \mathrm{~kg})$. Animals were weighed and divided into four treatment groups, with each group consisting of 6 animals: 4 males and 2 females. The 4 feeding treatments were: T1200-cut (mixed) grass (local village feed); T2-200 g A. villosa per day; T3-200 g C. gebanga pith per day; T4-100 g A. villosa plus $100 \mathrm{~g}$ C. gebanga per day. Proximate analysis was made to have information on the feed nutrient content.

The goats were given the above feeding treatments following the allocation to the group for a preliminary period of two weeks to accustom them to the feed. They were then re-weighed at the commencement of the designated 17-week experimental period. Average weights at this stage were relatively similar; 12.9, 13.1, 12.2, and $12.1 \mathrm{~kg}$ for groups T1, T2, T3, and T4 respectively with close range of age. The rations were given individually to the animals in each group. The levels chosen were based on the estimated amounts given to the goats by some innovative farmers in the villages.

A completely randomized design was used, with animals chosen randomly for each pen and each treatment. Goats were left to graze together during the day, and individually penned at night when the additional feed was given. Goats were weighed weekly and feed intake (the difference between amount offered and amount left) was also recorded on a daily basis.

Supplements were analyzed for their nutrient content at the laboratory of The University of Nusa Cendana in Kupang. Results obtained include the proximate analysis of supplements given to animals, average feed consumption, live weights and growth under trial conditions.

As all animals had the same number of repeated measurements, a multivariate method was used to analyses the data. Live weights and feed consumption were each analyzed using repeated measures analysis of variance.

\section{Composition of Supplements}

The results of proximate analysis of (mixed) cut grass, C. gebanga pith and $A$. villosa leaves, each collected from the communal village area are presented in Table 1. The cut grass comprised of a mixture of native grasses cut from the grazing area. The goats grazed during the

Table 1. Proximate analysis (DM Basis) of cut grass, Acacia villosa leaves and Corypha gebanga pith (\%)

\begin{tabular}{lccc}
\hline Nutrients & Cut grass & $\begin{array}{c}\text { Acacia } \\
\text { villosa }\end{array}$ & $\begin{array}{c}\text { Corypha } \\
\text { gebanga }\end{array}$ \\
\hline Crude protein & 6.20 & 19.34 & 3.03 \\
Crude fibre & 32.30 & 34.20 & 16.00 \\
Ether extract & 2.00 & 0.97 & $1)$ \\
Ash & 9.40 & 9.78 & - \\
Calcium & 0.13 & 0.12 & - \\
Phosphorous & - & 0.03 & - \\
\hline
\end{tabular}

Note: ${ }^{1)}=$ not analysed 
day and were fed supplements at night. This feeding management was applied following the common practice of farmers on their animals.

\section{RESULTS AND DISCUSSION}

\section{Effect of Feeding Treatments on Growth}

The overall results of the average goat live weight at week 17 were significantly different $(\mathrm{P}<0.05)$ among treatments $(13.16,13.98,14.60$, and $13.98 \mathrm{~kg}$ for $\mathrm{T} 1$, T2, T3 and T4, respectively) (Table 2). The weight gain among treatments within 6 weeks trial were also significantly different $(\mathrm{P}<0.05)(17,36,42,43 \mathrm{~g} / \mathrm{d} / \mathrm{h}$ ead for $\mathrm{T} 1, \mathrm{~T} 2, \mathrm{~T} 3$, and $\mathrm{T} 4$ respectively). There was a significant treatment $x$ week interaction, indicating different patterns of growth during the trial. Different feed resources and nutrients, in relation with seasons might contribute to the differences. The varied nutritional quality according to Khamseekhiew et al. (2012), was depended mainly on forage species used, of which contributed to the goat performance. The decrease in the average live weight after week 6 was possibly due to weight losses caused by parasite infestation, associated with seasonal changes, of which were most severe in the group receiving only cut grass. The average live weight of goats at the final period of the study (week 17), did not show

Table 2. Live weights $(\mathrm{kg})$ during the post-weaning period of goats in the feeding experiment given cut grass, A. villosa, C. gebanga or A. villosa plus C. gebanga

\begin{tabular}{ccccc}
\hline \multirow{2}{*}{ Week } & \multicolumn{4}{c}{ Treatments } \\
\cline { 2 - 5 } & $\mathrm{T} 1$ & $\mathrm{~T} 2$ & $\mathrm{~T} 3$ & $\mathrm{~T} 4$ \\
\hline Initial \\
weight & $12.90 \pm 0.70$ & $12.78 \pm 0.70$ & $12.20 \pm 0.70$ & $12.13 \pm 0.70$ \\
1 & $13.06 \pm 0.30$ & $13.39 \pm 0.37$ & $12.68 \pm 0.36$ & $12.38 \pm 0.24$ \\
2 & $13.48 \pm 0.30$ & $13.45 \pm 0.37$ & $12.91 \pm 0.36$ & $12.61 \pm 0.24$ \\
3 & $14.05 \pm 0.30$ & $14.03 \pm 0.12$ & $14.00 \pm 0.10$ & $13.51 \pm 0.17$ \\
4 & $13.50 \pm 0.29$ & $14.21 \pm 0.12$ & $13.80 \pm 0.10$ & $13.75 \pm 0.17$ \\
5 & $13.60 \pm 0.29$ & $14.26 \pm 0.12$ & $13.90 \pm 0.10$ & $13.83 \pm 0.17$ \\
6 & $13.63 \pm 0.40$ & $14.30 \pm 0.23$ & $13.96 \pm 0.78$ & $13.95 \pm 0.51$ \\
7 & $12.90 \pm 0.40$ & $13.85 \pm 0.23$ & $14.01 \pm 0.78$ & $13.95 \pm 0.51$ \\
8 & $13.00 \pm 0.40$ & $14.18 \pm 0.23$ & $12.63 \pm 0.78$ & $13.06 \pm 0.51$ \\
9 & $11.53 \pm 0.26$ & $12.96 \pm 0.25$ & $12.06 \pm 0.54$ & $12.23 \pm 0.37$ \\
10 & $11.88 \pm 0.26$ & $13.21 \pm 0.25$ & $12.73 \pm 0.54$ & $12.65 \pm 0.37$ \\
11 & $12.03 \pm 0.26$ & $13.46 \pm 0.25$ & $13.13 \pm 0.54$ & $12.96 \pm 0.37$ \\
12 & $11.91 \pm 0.27$ & $13.35 \pm 0.19$ & $13.33 \pm 0.53$ & $13.06 \pm 0.20$ \\
13 & $12.23 \pm 0.27$ & $13.46 \pm 0.19$ & $13.45 \pm 0.53$ & $13.38 \pm 0.20$ \\
14 & $12.58 \pm 0.27$ & $13.56 \pm 0.19$ & $13.58 \pm 0.53$ & $13.55 \pm 0.20$ \\
15 & $12.63 \pm 0.27$ & $13.60 \pm 0.19$ & $13.63 \pm 0.53$ & $13.58 \pm 0.20$ \\
16 & $12.78 \pm 0.27$ & $13.75 \pm 0.19$ & $13.75 \pm 0.53$ & $13.81 \pm 0.20$ \\
17 & $13.16 \pm 0.27$ & $13.98 \pm 0.19$ & $14.60 \pm 0.53$ & $13.98 \pm 0.20$ \\
\hline
\end{tabular}

Note: $\mathrm{T} 1=$ cut grass $($ Ad lib) basal diet; $\mathrm{T} 2=200 \mathrm{~g}$ A. villos $a$ per day; $\mathrm{T} 3=$ $200 \mathrm{~g}$ C. gebanga per day; T4=100 g A. villosa plus $100 \mathrm{~g} \mathrm{C.} \mathrm{gebanga}$ per day. better condition, resulted in the average of weight gain (T1, 2 g; T2, 10 g; T3, 20 g; T4, 16 g/d/head), which were much lower than those of the first- 6 week. Feeding management impaired with nutritional status as also stated by Pralomkarn et al. (2012), was one of the main factors affecting the virulence of the endoparasites in goats. Integrated pest management according to Pralomkarn et al. (1995), was useful as parasite control and might help to improve growth. All groups of goats commenced to grow again after week 9 but the cut grass group was very slow in health recovery, and unable to achieve an optimal growth rate compared to other groups. The variation and low nutrient content in each feeding treatment, seasonal effects, parasites and perhaps genetic potential of village goats, may have contributed to goat performance. However, further studies is needed to observe the effect of genetic factors on goat resistance to endoparasites. In general, the average live weight gain of goats across the regions tended to be lighter during dry seasons and more variable than those in wet season particularly after 12 mo of age. Major constraints contributes to low growth of goats in the villages, include poor management, parasite infestation, which is commonly occured during grazing time, and inefficient use of local feed resources.

The average live weight of goats for each week of the 17-week trial period show a small increase followed by a sharp drop after $8 \mathrm{wk}$, then a steady gain (Table 2). The lack of significant difference between feed supplements is likely due to the quantitatively important contribution of grazing during the day to total energy intake and hence growth rate. The use of locally available feeds (C. gebanga and A. villosa) as supplements in goat feeding appeared to help improved growth performance. The effect of feed supplement types on dry matter consumption was significant. It is likely that there was considerable variation between goats both within and between treatments in terms of physiological status, worm burdens and, according to Pralomkarn et al. (2012), the individual resistance to endoparasites. This condition would have contributed to the lack of significant difference between treatments. Goetsch et al. (2010), reported factors influencing levels and efficiency of production in relation with feeding behavior of goats using global positioning system collars method. Goats kept in confinement were compared with those left under grazing management practices during daylight, however, this method could not directly determine grazing.

The variation in the growth rate achieved from the study indicated that there was an unrealized potential for higher goat production in the villages. It could be improved by taking into consideration, some among others, the identified opportunities including the provision of feed, training of farmers on feeding, breeding, health management and veterinary services, and improvement on communal grazing areas. These were similar to recommendation of Pralomkarn et al. (2012), that the utilization of agricultural by-products and crop residues, and training on goat production at village level was necessary. Improvement of goat enterprises in villages was quite promising due to their roles and significance contribution, as food security (Eik et al., 2008), social 
status and source of income to farmers. It is however, depending very much on the availability of sufficient feed during critical times of dry seasons and health management. According to Djajanegara \& Misniwaty (2003), socio-cultural and economic function of goats in each community was also important, including aims, roles and economic status of goats, which might be varied between farmers. The level of goat performance observed in the village cannot be judged high or low without reference to the farmers' aims of rearing and the level of input acceptable to farmers.

The weight gain of supplemented grazing goats in the first six weeks of the trial, averaged 17, 36, 42, and $43 \mathrm{~g}$ per day for T1, T2, T3, and T4 respectively. Goats received acacia leaves (T2), palm pith (T3) and the combination of acacia-palm pith (T4), performed better than those fed natural grass only (T1). The average weight gain was relatively higher than the estimate weight gain of animals in the monitoring study (approximately 25 $\mathrm{g} / \mathrm{d} /$ head), but much lower than the average live weight gain of young local (Kacang) goats in other regions, of $>50 \mathrm{~g} / \mathrm{d}$ (Johnson et al., 1986). The results were closely related with suplemented feed consumption for which higher on goats fed palm pith and mixed acacia-palm pith (85 and $75 \mathrm{~g} / \mathrm{d})$. Whereas, goat fed natural grass had significantly lower growth rate than the other treatmnets. These figures indicating an eficiency in converting feed into weigth gain, which might be related with the types and nutrient content of each feedstuf (Table 1). A. villosa with high crude protein despite its high crude fiber, could generate high weight gain as compared to palm pith which had a lower crude fiber as wel as crude protein. In addition, due to seasonal effects and individual response of goats to endoparasites, the growth gradually decreased and the average final live weight was very low. It indicates that the indigenous type of goats in West Timor was experiencing such a long harsh environmental effect in dry seasons, when feed availability becomes the major problems limit productivity. Although live weight change was considered low and may not be enough to warrant feed and labor used, this trial might be useful as an alternative way to maintain village goat performance during critical dry seasons.

\section{The Effect of Treatments on Feed Consumption}

The effect of feed supplement types on consumption was significant $(\mathrm{P}<0.05)$. The average feed consumption was 52, 35, 85 and $75 \mathrm{~g}$ for cut grass, A. villosa, C. gebanga, and $A$. villosa plus C. gebanga, respectively (Figure 1 ). The goats given C. gebanga and mixed Acacia and Corypha consumed more feed than those given cut grass or $A$. villosa $(\mathrm{P}<0.01)$. These results suggest that feed consumption of goats was lower on $A$. villosa leaves than on palm pith and $A$. villosa plus palm pith. This may be due to high condensed tannin of $A$. villosa, varied between 3\%-7\% (Rubanza et al., 2003), and could be higher, due to species diferences which affect the feed palatability.

This study may have implications for farmers in terms of choice of supplement with the greatest potential for growth response per unit of feed consumed. A. villosa, with the highest protein supplement, and the dry matter would be a better choice than palm pith, if it was equally available in the village, taking into consideration an appropriate treatment to reduce the tannin content in Acacia. Wiryawan et al. (2001), found that well adapted ruminants (sheep) given $A$. villosa developed high tolerance of rumen microbe to tannin as the anti nutrient in the legume. The nutritive values of $A$. villosa had been widely discussed by researchers (Wiryawan et al., 2001;

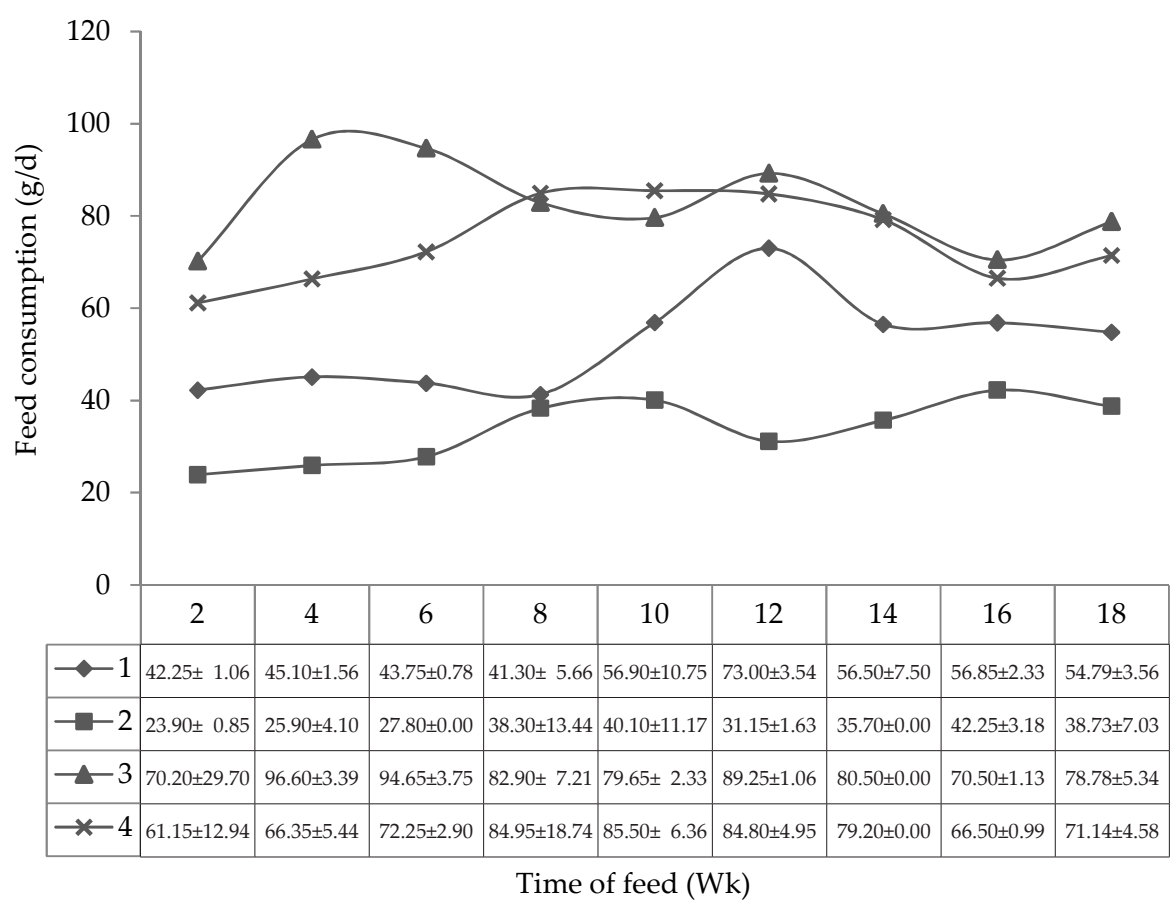

Figure 1. Consumption of grazing local goats supplemented with cut grass (G: - - ), A. villosa (AV: - --), C. gebanga (CG: - $\mathbf{\Delta}$-) and A. villosa plus C. gebanga (AV+CG: -x-) during the post weaning period from 32 to 49 weeks of age. 
Rubanza et al., 2003; Mulik \& Permana, 2009), including the toxin of tannin (Reed, 1995). In this regard, intensive goat feeding using the local forages as supplement, need proper management. Limea et al. (2009) stated that variation in nutritional status, had attributed to different goat performance, carcass quality, and farmers income. Therefore, feed efficiency in terms of the economic efficiency of village goat enterprises need to be seriously considered since an intensive goat production need more cost for feed and labor, as compared to those kept under a fully grazing system.

\section{CONCLUSION}

The use of locally available feeds (C. gebanga and A. villosa) as supplements in goat feeding appeared to improve the growth performance of local goats, relative to those given only cut grass supplements. A. villosa supplement would be a better choice as potential legume than palm pith, providing an appropriate management to minimize the effect of tannin as the anti nutrient affecting goat performance.

\section{REFERENCES}

Adriani. 2009. Pengaruh pemberian probiotik dalam pakan terhadap pertambahan bobot badan kambing kacang. Jurnal Ilmiah Ilmu-Ilmu Peternakan 12: 1-6.

Cyrilla, L., Z. Moesa, \& S. M. P. Putri. 2010. The efficiency of sheep farm production in Cibunian village, Pamijahan Sub District, Bogor. Med. Pet. 33:55-60.

Djajanegara, A. \& A. Misniwaty. 2003. Pengembangan usaha kambing dalam konteks social budaya masyarakat. Lokakarya Nasional Kambing Potong. Balai Penelitian Ternak, Pusat Penelitian dan Pengembangan Peternakan, Bogor.

Eik, L. O., G. C. Kifaro, S. M. Kiango, O. M. Nordaghen, J. Safari, \& L. A. Mtenga. 2008. Productivity of goats and their contribution to household food security in high potential areas of East Africa: A case of Mgeta, Tanzania. African Journal of Food Agricultural Nutrition and Development (AJFAND) 8: 278-289

Goetsch, T A. L., A. Gipson, A. R. Askar \& R. Puchala. 2010. Invited Review: Feeding behaviour of goats. J. Anim. Sci. 88:361-373. http://dx.doi.org/10.2527/jas.2009-2332

Ishaq, M., A. Farooq, \& U. Farooq. 2007. Economics of scale in small ruminant farming in Southern Nort West Frontier Province-Pakistan. J. Livestock Res. Rural Dev. 19(2).

Johnson, W. L., J. A. van Eys, \& H. A. Fitzhugh. 1986. Sheep and goats in tropical and subtropical agricultural systems. J. Anim. Sci. 63:1587- 1599.

Kanro, M. Z., A. Rouw, A. Widjono, Syamsudin, Amisnaipa, \& Atekan. 2003. Tanaman sagu dan pemanfaatannya di Propinsi Papua. Jurnal Litbang Pertanian 22: 116-124.
Khamseekhiew, B. O. Pimpa, \& V. Kongrith. 2011. Current situation of goat production in Surat Thani Province. Proceedings the $3^{\text {rd }}$ International Conference on Sustainable Animal Agriculture for Developing Countries. pp 111114.

Lestari, M. S. 2009. Penerapan teknologi pengolahan sagu rakyat di Kabupaten Jayapura Papua. Jurnal Ilmiah Tambua 8:440-445.

Limea, L. M. Boval, M. Mandonnet, G. Gacia, H. Archimede, \& G. Alexandre. 2009. Growth performance, carcass quality, and noncarcass components of indigenous Caribean goats under varying nutrituional densities. J. Anim. Sci. 87:37703781. http://dx.doi.org/10.2527/jas.2009-1834

Mulik, M. L. \& B. Permana. 2009. Improving growth rate of Bali Cattle grazing native pasture in wet season by supplementing high quality forages. JITV 14:192-199.

Padang \& Irmawati. 2007. Influence of sex and duration in feeding to carcass weight and percentage of local goat. J. Agrisistem. 3:13-20.

Pralomkarn, W., C., S. Kochapakdee, S. Saithanoo, \& S. Choldumrongkul. 1995. Effect of Supplementaion and internal parasites on growth of crossbred goat under village environments in southern Thailand. Thai J. Agric. Sci. 28, 27-36

Pralomkarn, W., C. Supakorn, \& D. Boonsanit. 2012. Knowledge in goats in Thailand. Mini Review. Wailailak, J. Sci \& Tech. 9:93-105.

Reed, J. D. 1995. Nutritional toxicologi of tannins and related polyphenols in forage legumes. J. Anim. Sci. 73: 15161528.

Rubanza, C. D. K, M. N. Shem, R. Otsyina, T. Ichinobe, \& T. Fujihara. 2003. Nutritive evaluation of some browse tree legume foliages native to semi arid areas in Western Tanzania. J. Anim. Sci. 16:1429-1437.

Setianah, R., S. Jayadi, \& R. Herman. 2004. Tingkah laku makan kambing lokal persilangan yang digembalakan di lahan gambut: studi kasus di Kalampangan, Palangkaraya, Kalimantan Tengah. Med. Pet. 27:111-122.

Simon, P. \& F. Ginting. 2005. Tantangan dan peluang pemanfaatan pakan lokal untuk pengembangan peternakan kambing di Indonesia. Lokakarya Nasional Kambing Potong. Pusat Penelitian dan Pengembangan Peternakan, Bogor.

Simon, P., F. Ginting \& A. Tarigan. 2006. Kualitas nutrisi rumput dan Brachiaria humidicula pada kambing. Seminar Nasional Teknologi Peternakan dan Veteriner, Sumatera Utara.

Sitorus, S. S. 2004. Pengaruh creep feed pada anak kambing kacang pra-sapih berbeda jenis kelamin. Med. Pet. 27:12-15.

Tangendjaja, B. \& E. Wina. 2000. Tannins and ruminants production in Indonesia. In: J. D. Brooker (Ed). Tannins in Livestock and Human Nutrition. ACIAR Proceedings No. 92: 40-43.

Wiryawan, K. G., Suryahadi \& A. S. Tjakradidjaja. 2001. In vitro degradation of Acacia villosa by ruminal microbes of adapted and non adapted sheep to Acacia feeding. Jurnal Peternakan dan Lingkungan 9:40-45. 